\title{
Upaya Meningkatkan Prestasi Belajar Matematika Siswa SMP Dengan Model Pembelajaran Kooperatif Tipe Jigsaw Pada Materi Himpunan
}

\author{
Januario Pareira ${ }^{*}$, Stanislaus Amsikan $^{2}$, Cecilia Novianti Salsinha ${ }^{3}$ \\ Universitas Timor \\ pareirajara1994@gmail.com ${ }^{1}$, amssta.ika@gmail.com $^{2}$
}

\begin{abstract}
Informasi Artikel
Abstrak

Revisi:

17 Juni 2021

Upaya meningkatkan prestasi belajar siswa dengan model pembelajaran kooperapetif tipe Jigsaw pada materi himpunan untuk siswa Kelas VII

Diterima:

19 Juli 2021

SMP Negeri 2 Tasifeto Timur dimana SMP Negeri 2 Tasifeto Timur prestasi belajar siswa tidak mencapai Standar Ketuntasan Minimal yang ditentukan oleh sekolah. Tujuan penelitian ini adalah untuk mengetahui prestasi belajar siswa dengan menerapkan model pembelajaran

Diterbitkan:

31 Agustus 2021 kooperapetif tipe Jigsaw pada materi himpunan. Jenis Penelitian yang digunakan dalam penelitian ini adalah Penelitian Tindakan Kelas (PTK). Subyek dalam penelitian ini adalah siswa kelas VII A1 sebanyak 18 siswa. Penelitian ini dilaksanakan dalam dua siklus. Teknik pengumpulan

Kata Kunci

Pembelajaran Kooperatif Jigsaw, Prestasi Belajar data dalam penelitian ini adalah hasil tes dan observasi. Data hasil penelitian menunjukan bahwa penggunaan model pembelajaran kooerapetif tipe Jigsaw dapat meningkatkan prestasi belajar siswa kelas VII SMP Negeri 2 Tasifeto Timur pada materi himpunan tahun ajaran 2020/2021. Hal ini dibuktikan dengan hasil tes setiap siklus yaiitu siklus I, nilai rata-rata siswa 66,69 dengan ketuntasan kelasnya $64,71 \%$ dan siklus II, nilai rata-rata siswa 71,77 dengan ketuntasan kelasnya 82,35\%. Berdasarkan hasil analisis data, peneliti menyimpulkan bahwa penggunaan model pembelajaran kooperapetif tipe Jigsaw dapat meningkatkan prestasi belajar siswa kelas VII SMP Negeri 2 Tasifeto Timur pada materi himpunan tahun ajaran 2020/2021.
\end{abstract}

\begin{abstract}
Efforts to improve the performance of student learning with a new cooperative learning model Jigsaw on the subject set material for the class VII for east regional high school students 2 Tasifeto where SMP Negeri 2 Tasifeto Timur student achievement does not reach the minimum completeness standard set by the school. The purpose of this study is to find out the performance of students' learning by applying jigsaw's type of kooerapective learning model to set material. The type of research used in this study is class-action research. The subject in this study is class VII a1 as many as 18 students. The study is conducted in two cycles. The datagathering technique in this study is the result of tests and observations. Research data show that use of the jigsaw type cooperative learning model can improve the ability of students studying class VII high school 2 Tasifeto east high students on the 2020/2021 doctrinal year complex. This is evidenced by the test results of each ydia cycle I, the student's average score of $64.71 \%$ with grade $64.71 \%$ and cycle ii, the student's average score of 71.77 with grade $82.35 \%$ sharp. Based on data analysis, researchers have concluded that the use of the new cooperative learning model jigsaw type could improve the performance of studying students in the SMPN 2 East Tasifeto class VII on materials set for 2020/2021.
\end{abstract}


MATH-EDU: Jurnal Ilmu Pendidikan Matematika

https://doi.org/10.32938/jipm.6.2.2021.42-49

Pareira, J., dkk.

\section{Pendahuluan}

Pendidikan adalah usaha sadar untuk menyiapkan peserta didik melalui kegiatan pengajaran atau latihan bagi peranannya di masa yang akan datang. Guru sebagai salah satu komponen yang sangat penting dalam proses belajar mengajar. Oleh karena itu guru harus dapat membuat suatu pengajaran menjadi lebih efektif juga menarik sehingga bahan pelajaran yang disampaikan membuat siswa merasa senang dan merasa perlu untuk mempelajari materi pelajaran tersebut, hal ini tercantum dalam undang-undang Republik Indonesia nomor 14 tahun 2005 tentang guru dan dosen.

Untuk meningkatkan prestasi belajar di sekolah diperlukan usaha yang berkesinambungan dari guru, merencanakan dan menciptakan situasi belajar baik di sekolah maupun di rumah. Belajar memerlukan situasi yang kondusif, nyaman, dan menyenangkan bagi siswa. Agar memungkinkan terjadinya pembelajaran aktif, kreatif dan inovatif dengan usaha ini dapat menghasilkan prestasi yang baik. Namun siswa selalu beranggapan bahwa matematika adalah pelajaran yang sulit, sehigga siswa kurang aktif dalam proses pembelajaran. Keaktifan siswa tergantung pada model pembelajaran yag diterapkan oleh guru. Siswa kurang aktif disebabkan guru masih menggunakan model pembelajaran konvensional dimana pembelajaran masih berpusat pada guru. Menurut Bakar (1981: 84), pembelajaran konvensional memiliki kelemahan yakni sangat membosankan karena kurangnya motivasi dan kreativitas dan kualitas pencapaian tujuan belajar relatif rendah karena pendidik sering hanya mengejar target sedangkan murid tidak dapat mengetahui kesulitan-kesulitan yang dihadapi. Sehingga kurangnya keaktifan siswa akan berdampak pada saat ulangan atau ujian yang hasil atau prestasi belajarnya tidak mencapai Kriteria Ketuntasan Minimal yang telah ditetapkan oleh sekolah. Berdasarkan hasil wawancara peneliti dengan salah satu guru Matematika di SMP Negeri 2 Tasifeto Timur yakni salah satu SMP di kabupaten Belu, menyatakan bahwa prestasi belajar siswa kelas VII khusus pada materi himpunan tidak mencapai Kriteria Ketuntasan Minimum (KKM) yaitu nilai 65 (ketetapan sekolah).

Permasalahan di atas menuntut guru memilih model pembelajaran yang tepat untuk menarik dan memicu perhatian peserta didik agar ikut secara aktif dalam kegiatan belajar mengajar. Salah satu model pembelajaran yang mampu melibatkan siswa aktif dalam pembelajaran sehingga terjadi interaksi multi arah adalah model pembelajaran kooperatif (cooperative learning). Jufri (2013: 112) menyatakan bahwa pembelajaran kooperatif merupakan salah satu model pembelajaran dimana peserta didik diorganisasikan untuk bekerja dan belajar dalam kelompok yang memiliki aturan-aturan tertentu. Model pembelajaran kooperatif yang mampu menekankan pada keaktifan siswa dalam pembelajaran adalah model pembelajaran kooperatif tipe Jigsaw. Arends (1997: 120), pembelajaran tipe Jigsaw adalah suatu tipe pembelajaran kooperatif yang terdiri dari beberapa anggota dalam satu kelompok yang bertanggung jawab atas penguasaan materi belajar dan mampu mengajarkan materi tersebut kepada anggota lain dalam kelompoknya.

Model pembelajaran kooperatif tipe Jigsaw telah diterapkan oleh beberapa peneliti sebelumnya yaitu penelitian Ning Endah Sri Rejeki (2009: 72) secara keseluruhan hasil penelitian telah mampu menjawab perumusan masalah, mencapai tujuan penelitian dan membuktikan hipotesis penelitian yaitu dengan penerapan model pembelajaran kooperatif tipe Jigsaw dapat meningkatkan ketuntasan belajar matematika kelas VIII G semester II SMP Negeri 2 Toroh Grobongan. Dari hasil pembelajran yang dilakukan oleh Dina Srikandi Ningsih (2013: 82) selama tiga siklus dan berdasarkan seluruh pembahasan serta analisis yang telah dilakukan dapat disimpulkan bahwa penerapan pembelajaran kooperatif tipe Jigsaw dapat meningkatkan proses belajar mengajar sehingga tujuan pembelajran dapat tercapai.

Solusi yang tepat untuk menyelesaikan masalah di atas adalah menerapkan model pembelajaran kooperatif tipe Jigsaw. Model pembelajaran kooperatif tipe Jigsaw adalah model pembelajaran kooperatif yang yang terdiri dari beberapa anggota dalam satu kelompok dimana setiap anggota bertanggung jawab untuk menguasai bagian materi belajar dan mampu 
MATH-EDU: Jurnal Ilmu Pendidikan Matematika

https://doi.org/10.32938/jipm.6.2.2021.42-49

Pareira, J., dkk.

megajarkann materi belajar tersebut kepada anggota lain dalam kelompok guna memperoleh hasil atau prestasi yang diharapkan. Dengan setiap anggota bertanggung jawab untuk menguasai materi belajar maka akan melibatkan siswa aktif dalam proses belejar mengajar.

\section{Pembelajaran Kooperatif Tipe Jigsaw}

Belajar adalah suatu kegiatan yang dilakukan dengan melibatkan dua unsur, yaitu jiwa dan raga. Belajar adalah serangkaian kegiatan jiwa dan raga untuk memperoleh perubahan tingkah laku sebagai hasil dari pengalaman individu dalam interaksi dengan lingkungan yang menyangkut aspek kognitif, afektif, dan psikomotorik. Gerak raga yang ditunjukkan harus sejalan dengan proses jiwa untuk mendapatkan perubahan (Syaiful 2002: 13). Menurut Slameto (2003: 2) mendefinisikan belajar sebagai suatu proses usaha yang dilakukan seseorang untuk memperoleh suatu perubahan tingkah laku yang secara keseluruhan, sebagai hasil pengalamannya sendiri dalam interaksi dengan lingkungannya. Darsono (2001: 32) juga berpendapat bahwa belajar adalah suatu kegiatan yang melibatkan individu secara keseluruhan, baik fisik maupun psikis, untuk mencapai perubahan dalam tingkah laku. Maka dapat diartikan belajar adalah suatu upaya yang di lakukan terencana melalui kegiatan latihan dan pengalaman yang melibatkan individu untuk menbentuk suatu perubahan.

Prestasi belajar merupakan hal yang tidak dapat dipisahkan dari kegiatan belajar, karena belajar merupakan proses, sedangkan prestasi adalah hasil dari proses belajar. Menurut syaifuddin Azwar (2002: 13) Prestasi belajar berarti hasil yang telah dicapai oleh murid sebagai hasil belajarnya, baik berupa angka, huruf, atau tindakan yang mencerminkan hasil belajar yang telah dicapai masing- masing anak dalam periode tertentu. Winkel (1996: 162) mengatakan bahwa prestasi belajar adalah suatu bukti keberhasilan atau kemampuan belajar seorang siswa dalam melakukan kegiatan belajarnya sesuai dengan bobot yang dicapainya. Maka dapat diartikan bahwa prestasi belajar adalah hasil dari usaha seseorang yang telah melakukan kegiatan belajarnya. Proses belajar mengajar siswa dikatakan berprestasi jika sudah melakukan evaluasi, guna mengetahui tinggi rendahnya prestasi belajar siswa, dengan kata lain prestasi belajar adalah nilai yang baik dari suatu perilaku seseorang yang dicapai dengan usaha. Dengan demikian untuk meningkatkan prestasi belajar disekolah diperlukan usaha yang berkesinambungan dari guru, merencanakan dan menciptakan situasi belajar baik disekolah maupun dirumah. Belajar memerlukan situasi yang kondusif, nyaman, dan menyenangkan bagi siswa. Agar memungkinkan terjadinya pembelajaran aktif, kreatif dan inovatif dengan usaha ini dapat menghasilkan prestasi yang baik. Ada pun fungsi utama prestasi belejar menurut Roestiyah (2001: 72) antara lain: 1. Prestasi belajar sebagai indikator kualitas dan kuantitas pengetahuan yang telah dikuasai peserta didik. 2. Prestasi belajar sebagai lambang pemuasan hasrat ingin tahu. Para ahli psikologi biasanya menyebut hal ini sebagai "tendensi keingintahuan (couriosity) dan merupakan kebutuhan umum manusia". 3. Prestasi belajar sebagai bahan informasi dalam inovasi pendidikan. Asumsinya adalah prestasi belajar dapat dijadikan pendorong bagi siswa dalam meningkatkan ilmu pengetahuan dan teknologi, dan berperan sebagai umpan balik (feedback) dalam meningkatkan mutu pendidikan.4. Prestasi belajar sebagai indikator intern dan ektern dari suatu institusi pendidikan. Indikator intern dan ektern dalam arti bahwa prestasi belajar dapat dijadikan indikator tingkat produktivitas suatu instuisi pendidikan. Asumsinya adalah kurikulum yang digunakan relevan dengan kebutuhan masyarakat dan siswa. Indikator ekstern dalam arti bahwa tinggi rendahnya prestasi belajar dapat dijadikan indikator tingkat kesuksesan siswa dimasyarakat. Asumsinya adalah kurikulum yang digunakan relevan pula dengan kebutuhan masyarakat. Prestasi belajar dapat dijadikan indikator daya serap (kecerdasan) siswa. Dalam proses pembelajaran, siswa menjadi fokus utama yang harus diperhatikan, karena siswalah yang diharapkan dapat menyerap seluruh materi pelajaran.

Pembelajaran kooperatif merupakan sekumpulan strategi pengajaran yang dirancang untuk mendidik siswa bekerja sama dalam kelompok dan interaksi antar siswa dalam 
memaksimalkan kondisi belajar untuk mencapai tujuan pembelajaran. Menurut Jufri (2013: 112) menyatakan bahwa pembelajaran kooperatif merupakan salah satu model pembelajaran dimana peserta didik diorganisasikan untuk bekerja dan belajar dalam kelompok yang memiliki aturan-aturan tertentu. Ketergantungan seperti itulah yang selanjutnya akan memunculkan tanggung jawab individu terhadap kelompok dan keterampilan interpersonal dari setiap anggota kelompok. Setiap individu akan saling membantu, mereka akan mempunyai motivasi untuk keberhasilan kelompok, sehingga setiap individu akan memiliki kesempatan yang sama untuk memberikan kontribusi demi keberhasilan kelompok.

Pembelajaran kooperatif tipe Jigsaw memiliki tujuan untuk melatih siswa agar terbiasa dalam diskusi dan bertanggung jawab memahamkan siswakan lain dengan materi yang dipelajarinya. Tujuan pembelajaran kooperatif tipe jigsaw menurut Anam (2000: 3) adalah sebagaiberikut: 1 . Menyajikan model alternatif disamping ceramah dan membaca. 2. Mengkaji kebergantungan positif dalam menyampaikan dan menerima informasi diantara anggota kelompok untuk mendorong kedewasaan berfikir. 3. Menyediakan kesempatan berlatih bicara dan mendengarkan untuk kognisi peserta didik dalam menyampaikan informasi.

Proses pembelajaran kooperatif tipe Jigsaw memiliki dua bagian pembelajran yakni kelompok asal dan kelompok ahli. Siswa dalam kelompok asal dibagi untuk membentuk kelompok ahli. Siswa dalam kelompok ahli mempelajari materinya dan siap mengajarkan materi tersebut kepada siswa lain di kelompok asalnya. menurut Anam (2000: 3) membagi model pembelajran kooperatif tipe Jigsaw menjadi dua tahap antara lain: 1. Tahap kooperatif, pada tahap ini peserta didik ditempatkan dalam kelompok kecil dengan beranggotakan 5 peserta didik atau lebih. Kelompok ini disebut kelompok kooperatif dan menerima sebagian informasi atau bacaan dari satu paket informasi yang segera dibahas/dipecahkan dalam kelompok kooperatif tersebut. 2. Tahap ahli, sebagai anggota yang mendapat tugas tertentu peserta didik mendapat tugas yang sama melakukan hal-hal sebagai berikut: a. Belajar bersama dan menjadi ahli dalam bidang informasi (bacaan) yang menjadi tugasnya. b. Memecahkan cara mengajarkan informasi (isi bacaan) yang telah dikuasai kedalam kelompok kooperatif. c. Tahap Lima Serangkai, pada tahap ini peserta didik kelompok ahli kembali kekelompok kooperatifnya (kelompok asal). Dengan sendirinya kualitas pemecahan masalah akan lebih baik karena dikerjakan bersama oleh para ahli dibidangnya.

Dalam proses pembelaran tipe Jigsaw siswa dalam kelompok dipilih secara acak. menurut Slavin (1995: 122) mengemukakan bahwa dalam Jigsaw para siswa bekerja dalam kelompok/tim yang heterogen. Para siswa tersebut diberikan tugas untuk membaca beberapa bab atau unit dan diberikan lembar ahli yang terdiri atas topik-topik yang berbeda yang harus menjadi fokus masing-masing anggota tim saat mereka membaca. Setelah semua anak selesai membaca, siswa-siswa dari tim yang berbeda, fokus topik yang sama bertemu dalam kelompok ahli untuk mendiskusikan topik mereka sekitar 30 menit. Para ahli tersebut kemudian kembali kepada tim mereka dan secara bergantian mengajari teman satu timnya mengenai topik mereka.Yang terakhir adalah para siswa menerima penilaian yang mencakup seluruh topik, dan skor kuis akan menjadi skor tim.

Kelebihan jigsaw adalah pembelajaran yang efektif dan efisien. Hal tersebut dikarenakan selain prestasi akademik siswa lebih baik, hal lain seperti kerja sama, keakraban, komunikasi antar siswa maupun dengan guru akan lebih baik seiring meningkatnya kepercayaan diri siswa. Hal ini didukung dengan penelitian Tran \& Lewis (2012: 15) yang menyatakan bahwa pembelajaran kooperatif khususnya jigsaw memberikan hasil yang positif terhadap sikap siswa dalam belajar. Siswa akan lebih perhatian, lebih mandiri, banyak belajar dan merasa lebih percaya diri. Siswa merasa sangat percaya diri dalam mengemukakan pendapatnya dan menjelaskan apa yang siswa tahu kepada kelompoknya.

Sintaks pembelajaran kooperatif tipe Jigsaw dalam penelitian ini adalah sebagai berikut: 1. Siswa dibagi atas 4 kelompok asal, dimana kelompok asal I dan II berjumlah 5 orang dan 
kelompok asal III, dan IV berjumlah 4 orang. 2. Pembentukan kelompok ahli yang anggotanya merupakan perwakilan dari setiap kelompok asal dan materi setiap kelompok ahli berbedabeda. 3. Siswa dalam kelompok ahli berdiskusi. 4. Selesai berdiskusi dalam kelompok ahli, setiap perwakilan anggota kelompok kembali ke kelompok asal untuk mengajarkan temantemannya. 5. Siswa dalam kelompok asal berdiskusi. 6. Mempresentasikan hasil diskusi. 7. Guru mengevaluasi dan memberikan kesimpluan dan memberi nilai pada setiap kelompok asal.

\section{Metode}

Metode yang digunakan dalam penelitian ini adalah metode Penelitian Tindakan Kelas (PTK). Subjek penelitian ini adalah siswa kelas VII A1 di SMP Negeri 2 Tasifeto Timur, sebanyak 18 siswa. Penelitian ini telah dilaksanakan pada semester ganjil tanggal 2 Oktober -6 November 2020 tahun ajaran 2020/2021 di SMP Negeri 2 Tasifeto Timur, Desa Tohe, kecamatan Raihat, kabupaten Belu.

Penelitian tindakan kelas ini terdiri dari dua siklus. Dalam siklus I berlangsung selama dua minggu dengan dua kali pertemuan. Pertemuan pertama adalah kegiaatan belajar mengajar dan pertemuan kedua adalah tes. Siklus II berlangsung selama tiga minggu dengan tiga kali pertemuan. Pertemuan pertama dan kedua adalah kegiatan belajar mengajar dan pertemuan ketiga adalah tes. Setiap siklus dirancang dengan melalui empat tahap yaitu perencanaan/persiapan, tindakan, observasi dan refleksi.

Metode analisis data dalam penelitian ini adalah analisis data hasil observasi siswa dan guru dan analisis data hasil tes. analisis data hasil tes ada dua yaitu ketuntasan perorangan dan ketuntasan kelas. Metode analisis data hasil pengamatan siswa diperoleh berdasarkan pedoman pengamatan yang di lakukan pada setiap siklus dan dapat dianalisa dengan rumus sebagai berikut:

$\mathrm{N}=\mathrm{R} / \mathrm{SM} \times 100 \%$ Purwanto (2009: 102)

Keterangan:

$\mathrm{N} \quad=$ nilai yang dicari atau diharapkan

$\mathrm{R} \quad=$ skor yang diperoleh

$\mathrm{SM} \quad=$ skor maksimum

$100=$ bilangan tetap

Dengan kategori pada tabel berikut:

Tabel 1. kategori hasil pengamatan siswa

\begin{tabular}{cc}
\hline Nilai & Kategori \\
\hline $0-20$ & Sangat kurang \\
$21-40$ & Kurang \\
$41-60$ & cukup \\
$61-80$ & Baik \\
$81-100$ & sangat baik \\
\hline
\end{tabular}

Metode analisis data hasil tes dilakukan dengan langkah-langkah:

a. Memeriksa, menskor dan menilai hasil kerja siswa.

b. Untuk mengetahui ketuntasan siswa terhadap materi dari setiap siklus digunakan rumus : Ketuntasan presentase $=\mathrm{T} / \mathrm{Tt} \times 100 \%$ (Lie, 2005: 85)

Keterangan: 


\section{T: Jumlah skor yang diperoleh siswa}

Tt: Jumlah Skor total

Untuk mengetahui presentase dari pencapaian ketuntasan kelas digunakan rumus:

Ketuntasan presentase $=$ S $/ \mathrm{T}$ x $100 \%$ (Lie, 2005: 85)

Keterangan :

S: jumlah siswa yang mencapai ketuntasan

T: jumlah siswa dalam kelas

c. Menyajikan data sedemikian, sehingga dapat memberikan kemungkinan adanya penarikan kesimpulan.

Indikator keberhasilan dalam penelitian ini adalah jika ketuntasan kelas lebih besar atau sama dengan $65 \%$, maka proses pembelajaran yang dilaksanakan dengan menerapkan model pembelajaran kooperatif tipe Jigsaw dikatakan berhasil, tetapi jika ketuntasan kelas kurang dari 65\%, maka pembelajaran yang dilaksanakan dengan menerapkan model pembelajaran kooperatif tipe Jigsaw belum berhasil dan dilanjutkan pada siklus berikutnya dengan memperhatikan mengenai tahapan dalam model perbelajaran.

\section{Hasil dan Pembahasan}

Proses penelitian dilakukan di kelas VII A1 SMP Negeri 2 Tasifeto Timur Tahun ajaran 2020/2021. Materi yang diajarkan adalah himpunan dengan model pembelajaran yang digunakan adalah model pembelajaran kooperatif tipe Jigsaw dan datanya diperoleh melalui hasil observasi dan hasil tes. Sesuai dengan gagasan penelitian, maka penelitian tindakan kelas yang ditempuh dengan dua siklus. Pada kegiatan pembelajaran pada siklus I berlangsung dalam dua kali pertemua dengan pertemuan pertama adalah kegiatan belajar mengajar dan kegiatan ke dua adalah tes. Pertemua pertama dilaksanakan pada Jumat, 2 Oktober 2020 dengan jumlah siswa yang hadir 18 orang dengan indikator yang ingin dicapai antara lain yakni menyatakan masalah sehari-hari dalam bentuk himpunan dan mendata anggotanya, menyebutkan anggota dan bukan anggota dari suatu himpunan dan menyatakan suatu himpunan. Pertemuan ke dua dilaksanakan pada Jumat, 9 Oktober 2020 dengan siswa yang hadir 17 orang.

Pada siklus I dilakukan dengan empat tahap yaitu perencanaan, tindakan, observasi dan refleksi. Pada tahap perencanaan peneliti mempersiapkan perangkat pembelajaran. Tahap tindakan dilakukan dengan langka-langka kegiatan awal, kegiatan inti dan penutup. Tahap observasi dilakukan oleh mitra peneliti. Kemudian pada tahap refleksi peneliti melihat hal-hal yang akan diperbaiki pada siklus selanjutnya.

Data hasil tes siklus I, dari 17 siswa yang mengikuti tes diperoleh rata-rata hasil tes adalah 66,69, 11 siswa diantaranya tuntas dan 6 siswa belum tuntas sehingga diperoleh ketuntasan kelas $64,71 \%$. Hasil tes siklus I belum memenuhi kriteria ketuntasan yang ditetapkan yaitu kriteria ketuntasan minimal (KKM) 65. Hal ini terjadi karena sintaks model pembelajaran kooperatif tipe Jigsaw pada siklus I merupakan hal baru bagi siswa dimana partisipasi anggota dalam kelompok asal yang bertanggung jawab untuk mengajari teman kelompoknya terdapat beberapa siswa yang kurang percaya diri dalam menyampaikan pendapat atau bertanya saat berdiskusi. Sehingga dalam diskusi kelompok mengerjakan latihan soal tidak tepat pada waktu yang telah ditentukan untuk dipresentasikan.

Berdasarkan hasil tes pada siklus I, prestasi belajar belum mencapai indikator kebehasilan yang ditetapkan oleh sekolah, maka peneliti melakukan perbaikan untuk siklus berikut, antara lain: 1. Memotivasi siswa agar aktif dalam proses belajar mengajar. 2. Membimbing siswa agar aktif dan bebas berpendapat dalam proses belajar mengajar sehingga terjadi interaksi antar siswa dengan guru dapat terlaksana dengan baik. 3. Mengingatkan kepada siswa untuk gunakan waktu sebaik mungkin agar proses pembelajaran berjalan sesuai dengan yang harapkan. 4. Untuk 
peneliti, tingkatkan bimbingan untuk setiap kelompok ahli dan kelompok asal agar memperoleh prestasi belajar yang diharapkan.

Proses penelitian pada siklus II dilaksanakan 3 kali pertemuan dengan pertemuan pertama dan kedua kegiatan belajar mengajar dan pertemuan ketiga adalah tes. Pertemuan pertama dilaksanakan pada hari Jumat, 16 Oktober 2020 dengan jumlah siswa yang hadir 17 orang, indikator yang ingin dicapai mengenal notasi himpunan kosong, menggambar dan membaca diagram Venn dari suatu himpunan, menyelesaikan masalah konstekstual yang berkaitan dengan diagram Venn. Pertemuan kedua dilaksanakan pada hari Jumat, 23 Oktober 2020 dengan jumlah siswa yang hadir 17 orang, indikator yang ingin dicapai memahami dan menentukan banyaknya himpunan bagian suatu himpunan, menyatakan kardinalitas suatu himpunan, menyebutkan himpunan bagian dari suatu himpunan. Pertemuan ketiga dilaksanakan pada hari Jumat, 6 November 2020 dengan jumlah siswa yang hadir 17 orang.

Pada siklus II dilakukan dengan 4 tahap yaitu, perencanaan, tindakan, observasi dan refleksi. Pada tahap perencanaan, peneliti mempersiapkan perangkat pembelajaran. Tahap tindakan dilakukan dengan langkah-langkah kegiatan, kegiatan inti dan penutup. Tahap observasi dilakukan oleh mitra peneliti. Kemudian pada tahap refleksi peneliti melakukan perbandingan hasil tes dari siklus I ke siklus II. Dengan hasil tes siklus II, dari 17 siswa yang mengikuti tes terdapat 3 siswa yang belum mencapai standar ketuntasan minimum dan 14 siswa yang mencapai standar ketuntasan sehingga diperoleh presentase ketuntasan kelas sebesar $82,35 \%$. Hasil tes siklus II sudah memenuhi kriteria ketuntasan yang ditetapkan yaitu kriteria ketuntasan minimal (KKM) 65. Hal ini terjadi karena pada siklus II semua siswa sudah aktif dalam menjelaskan submateri yaitu menggunakan konsep himpunan dan diagram Venn dalam pemecahan masalah. Dalam proses pembelajaran semua siswa sudah mulai aktif dalam menyampaikan pendapat atau bertanya saat berdiskusi untuk kegiatan belajar mengajar dan diskusi antara anggota kelompok berjalan dengan baik. Sehingga dikatakan bahwa siswa mulai memahami sintaks model pembelajaran kooperatif tipe Jigsaw yang digunakan dalam proses pembelajaran di lokasi penelitian.

Dari hasil tes siklus I ke siklus II dapat dilihat bahwa rata-rata hasil tes meningkat dengan rata-rata dari 66,69 menjadi 71,77, ketuntasan perorangan dari 11 orang menjadi 14 orang dan ketuntasan klasikal dari 64,71\% menjadi $82,35 \%$. Hal ini terjadi karena siswa mulai memahami tentang cara belajar dengan menggunakan model pembelajaran kooperatif tipe Jigsaw. Ditinjau dari hasil lembar observasi dan data hasil tes pada siklus I dan siklus II menunjukkan bahawa model pembelajaran kooperatif tipe Jigsaw dapat meningkatkan prestasi belajar siswa digunakan sebagai salah satu dalam model pembelajaran di SMP Negeri 2 Tasifeto Timur untuk mengembangkan konsep, menguasai materi, dan berdiskusi dalam kelompok.

\section{Simpulan}

Hasil analisis data siklus I dan II dalam penelitian dapat disimpulkan bahwa penggunaan model pembelajaran kooperatif tipe Jigsaw dapat meningkatkan prestasi belajar siswa kelas VII SMP Negeri 2 Tasifeto Timur pada materi himpunan tahun akademik 2020/2021. Peningkatkan prestasi belajar matematika siswa ini dapat dilihat dari nilai rata-rata pada setiap siklus, dimana siklus I nilai rata-rata siswa 66,69 dengan ketuntasan perorangan sebanyak 11 siswa, dan ketuntasan kelasnya sebesar $64,71 \%$. Siklus II nilai rata-rata siswa 71,77 dengan ketuntasan perorangan sebanyak 14 siswa, dan ketuntasan kelasnya sebesar $82,35 \%$. Artinya, siklus I ke siklus II, ketuntasan kelas mengalami peningkatan sebesar 17,64\%.

\section{Rekomendasi}

Berdasarkan kesimpulan di atas, maka peneliti menyarankan kepada guru mata pelajaran matematika dapat memilih model pembelajaran yang tepat untuk melibatkan siswa secara aktif dalam proses belajar mengajar sehingga dapat meningkatkan prestasi belajar siswa. 
MATH-EDU: Jurnal Ilmu Pendidikan Matematika

https://doi.org/10.32938/jipm.6.2.2021.42-49

Pareira, J., dkk.

\section{Referensi}

Anam, K. 2000. Implementasi Cooperatif Learning adaptasi Model Jigsawdan Field Study. Jakarta: Dirjen Dinasmen.

Arends, R. I. 1997. Classroom Intruction And Management. New york: McGraw-Hill Companies, Inc.

Azwar, S. 2002. Tes Prestasi, Yogyakarta: Liberty

Bakar, M. A. 1981. Pedoman Pendidikan dan Pengajaran. Surabaya: Usaha Nasional.

Darsono. 2001. Belajar dan pembeljaran. Semarang: IKIP Semarang Press.

Jufri, A. W. 2013. Belajar dan Pembelajaran Sains dan Aplikasinya. Yogyakarta: Suka-P.

Lie, A. 2005. Cooperative learning (mempraktekkan Cooperative learning di ruang- runag kelas. Jakarta: Grasindo Gramedia Widiasarana Indonesia.

Ningsih D. S. 2014. Meningkatkan Prestasi Belajar Siswa Melalui Model Pembelajaran Kooperatif Tipe Jigsaw Pada Siswa SMK Negeri 3 Meulaboh Tahun 2013/2014. Jurnal ilmiah pendidikan matematika 1 (1), 67-84.

Presiden Republik Indonesia. 2005. Undang-Undang nomor 14 tahun 2005 Tentang Guru Dan Dosen. Lembaran Negara RI Tahun 2005, no17. Sekretariat Negara: Jakarta.

Purwanto. 2009. Evaluasi Hasil Belajar. Surakarta: Pustaka Belajar.

Rejeki, N. E. S. 2009.Meningkatkan Hasil Belajar Matematika Melalui Model Pembelajaran Kooperatif Tipe Jigsaw Pada Siswa Kelas VIII G Semester 2 SMP Negeri 2 Toro Grobongan, jurnal Lemlit 3(2), 61-73.

Roestiyah. 2001. Strategi Belajar Mengajar. Jakarta: Rineka Cipta.

Slameto. 2003. Evaluasi Pendidikan. Jakarta: Bhumi Aksara.

Slavin, R. E. 1995.Cooperative Learning (2nd ed.). Boston, MA: Allyn \& Bacon.

Syaiful. 2002. Strategi Belajar Mengajar. Jakarta: Rineka Cipta

Tran, V. D. \& Lewis R. 2012. Effects of Cooperative Learning on Students at an Giang University in Vietnam. International education studies, 5(1), 86-89.

Winkel W.S. 1996. Bimbingan Dan Konseling. Jakarta: Gramedia Widiasmara Indonesia 